\title{
Articulo Original / Original Article Antibacterial potential of essential oils against planktonic and sessile cells of Escherichia coli isolated from diarrhea cases in swine
}

\author{
[Potencial antibacteriano de aceites esenciales contra células de Eschericbia coli planctónicas \\ y sésiles aisladas de diarrea porcina]
}

\author{
Franciana Aparecida Volpato Bellaver ${ }^{1}$, Anildo Cunha Junior ${ }^{2}$, Thais Carla Dal Bello ${ }^{1}$, Ana Julia Longo Neis ${ }^{3}$, \\ Marcella Zampoli Troncarelli ${ }^{1} \&$ Alessandra Farias Millezi ${ }^{1}$ \\ ${ }^{1}$ Instituto Federal Catarinense, Campus Concórdia, Santa Catarina, Brazil \\ ${ }^{2}$ Embrapa Suínos e Aves, Concórdia, Santa Catarina, Brazil \\ ${ }^{3}$ Universidade do Contestado, Campus Concórdia, Santa Catarina, Brazil
}

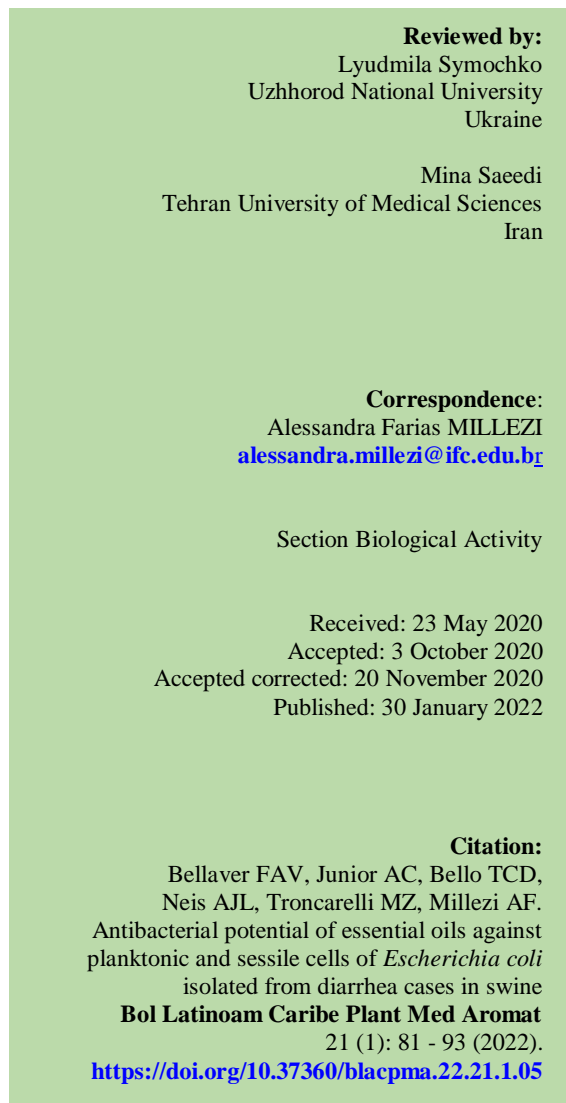

Abstract: Escherichia coli is a pathogen associated with infections in piglets in the post-weaning phase, its pathogenicity is related to the animal's susceptibility to bacterial enterotoxins. The objective of the present study was to determine the EOs activity against $E$. coli strain, in the form planktonic and sessile. Although the Disc-Diffusion tests to determine the Minimum Inhibitory Concentration, do not fully corroborate with the other analyzes of this study, it was noticed bacteria inhibition. The EOs were prepared at $0.4 \%, 0.8 \%$ and $1.0 \%$ for tests. The tested EOs were effective against $E$. coli planktonic cells $(p<0.05)$. As for the sessile cells, the most significant result was inhibition and $100 \%$ sessile cells at the concentration of $1.0 \%$ of Cymbopogon citratus EO. Although there was resistance in some treatments, the tested EOs demonstrated inhibition capacity, constituting promising alternatives for the control of E. coli, especially of planktonic cells.

Keywords: Antimicrobial; Enterobacteria; Plants; Biofilms; Infections

Resumen: Escherichia coli es un patógeno asociado con infecciones en lechones en la fase posterior al destete, su patogenicidad está relacionada con la susceptibilidad del animal a las enterotoxinas bacterianas. El objetivo del presente estudio fue determinar la actividad de contra $E$. coli, en la forma planctónico y sésil. Aunque las pruebas de difusión de disco para determinar la concentración inhibitoria mínima, no corroboran completamente con los otros análisis de este estudio, se observó inhibición de la bacteria. Las soluciones basadas en AE se prepararon al $0.4 \%, 0.8 \%$ y $1.0 \%$ para pruebas. Los AEs probados fueron efectivos contra las células planctónicas $(p<0.05)$. En cuanto a las células sésiles, el resultado más significativo fue la inhibición y el 100\% de las células sésiles a la concentración de 1,0\% de Cymbopogon citratus. Aunque hubo resistencia en algunos tratamientos, los AEs probados demostraron capacidad de inhibición, constituyendo alternativas prometedoras para el control de E. coli, especialmente de células planctónicas.

Palabras clave: Antimicrobiano; Enterobacterias; Plantas; Biopelículas; Infecciones 


\section{INTRODUCTION}

Enterotoxigenic Escherichia coli (ETEC) causes diarrhea in piglets, weight loss, greater feed recovery, sudden death, or disposal. According to Caramori Junior et al. (2010), diarrheal syndrome causes 6\% mortality in piglets. Neonatal colibacillosis occurs by ingesting bacteria of maternal and environmental origin; absence of natural defenses, such as intestinal bacteria and gastric barrier; the presence of receptors for bacteria in the intestinal cells of newborns; and high susceptibility of animals to enterotoxins produced by E. coli (Barcellos \& Oliveira, 2012).

The increase in production rates in modern swine farming directly contributes to the intense exposure of swine to a varied number of diseases that, as a consequence, result in the indiscriminate use of antimicrobials, which determines the pressure of artificial selection of multidrug-resistant bacterial strains. E. coli must be considered as an important pathogen in swine, due to its important antimicrobial resistance and ability to transmit horizontally, which results in serious damage to public health (Silva et al., 2015).

When considering the resistance of microorganisms, one of the factors that must be evaluated is the ability of microbial cells to the group, leading to the formation of microbial biofilms. Biofilms can be termed as organizations of sessile bacteria that form a physical barrier, consisting of DNA, proteins, and exopolysaccharides (EPS), biofilm-associated organisms also differ from their planktonic (freely suspended) counterparts concerning the genes that are transcribed (Donlan, 2002) One of those outstanding properties is the increase of sessile cell resistance to host defenses, biocides, antibiotics and various physiochemical agents (Donlan, 2002; Stewart \& Costerton, 2005).

Due the high frequency of resistance of pathogens to antimicrobials, search alternative agents that have the same or greater bactericidal effect becomes essential. Aromatic and medicinal plants have been used for thousands of years in different cultures around the world, especially because they contain essential oils (EOs), formed from secondary metabolic pathways and defined as complex mixtures of volatile, lipophilic substances, usually odorous and liquid (Simões \& Spitzer, 2004). The factors that arouse interest in the study of EOs as biocidal agents are numerous, such as the fact that they have antibacterial, antifungal, insecticidal, antioxidant, anti-inflammatory, and larvicidal pharmacological properties. (Guimarães et al., 2011; Alexopoulos et al., 2011; Pauliquevis \& Favero, 2015; Gomes et al., 2016).

Many EOs already have the designation "Generally Recognized As Safe" (GRAS) or "Generally Considered Safe" obtained by the American Food and Drug Administration (FDA), as they are designated as safe by specialists, for addition to food and ingestion by humans and animals. EOs can be seen as allies of nature, as they are relatively easy to obtain, have low toxicity, and are biodegradable (Isman, 2000).

The species Cymbopogon citratus (A.D.) Stapf., belonging to the family Poaceae (Gramineae), is popularly known by more than 20 names, among this lemongrass, grass-saint lemon verbena, fragrant grass, cidreira grass, lesser citronella and true cidreira herb (Cardoso et al., 2000). Studies suggest that the antibacterial activity of $C$. citratus oil is mainly due to the and citral components present in it (Oliveira et al., 2010). The EO Thymus vulgaris is rich in timol, presenting traces of carvacrol, scientifically recognized potent bactericides, and fungicides (Essawi \& Srour, 2000). Recent studies prove the antibacterial activity of $T$. vulgaris as being effective against gram-positive and Gram-negative bactéria (Millezi et al., 2012). Syzygium aromaticum (clove) is used as a spice in almost all the world's fair. Bud Oil of clove has natural behavior and the main properties include antioxidant, insecticidal, antifungal, and antibacterial properties. By tradition, it has been used in food preservation as a flavoring and antimicrobial substance (Velluti et al., 2003, Saeed et al., 2013). Ocimum basilicum L. (Lamiaceae family) - basil is a herb, originating probably from the tropical and subtropical parts of India. It is used to treat various infections, skin and liver disorders, colds, coughs, fever, and malaria (Gupta et al., 2002). In Brazil, it is used as a spice in foods. The survey results have shown a pronounced antimicrobial activity of basil EO on all tested strains of Gram (+) and Gram (-) (Gajendiran et al., 2016; Stanojevic et al., 2017).

Most research reports the Minimum Inhibitory Concentration (MIC) or Minimum Bactericidal Concentration (MBC) tests, but it is also relevant to test EOs against viable cells and especially sessile cells, due to their greater resistance. Studies in the agricultural area, for the control of 
undesirable microorganisms, are important. Therefore, the present study aimed to evaluate the antimicrobial activity EOs of $S$. aromaticum (clove), T. vulgaris (thyme), O. basilicum (basil) and $C$. citratus (lemongrass), against the E. coli strain, in planktonic and sessile forms, isolated from cases of swine diarrhea.

\section{MATERIAL AND METHODS}

Local of execution of experiments and bactéria strain

The biofilm experiments were carried out at the Veterinary Microbiology Laboratory, and the chromatographic analyzes of the EOs were performed at the Packaging Analysis Laboratory; both from Federal Institute of Santa Catarina (IFC) Campus Concórdia, Santa Catarina State, Brazil. The E. coli strain was provided by the Animal Health Diagnosis Center (CEDISA) located in Concórdia, and obtained from a case of diarrhea in a seven-day-old piglet in 2017.

\section{Collect of plants, preparation of desiccata and species identification}

The plants Ocimum basilicum (basil) and Cymbopogon citratus (lemongrass) were collected at dawn, in the region of Concórdia, in April 2017. Parts of these plants were selected to perform the exsiccates. All procedures were performed according to Machado \& Barbosa (2010). To obtain the EOs, the plants were prepared less than 1 hour postharvest. Most expressive parts of the plants were selected for making the exsiccates. After a month of pressing the plants (recommendation of the Herbarium), for their complete drying and formation of the exsiccatae, they were sent to the Herbário Padre Balduíno Rambo of the Integrated Regional University of Alto Uruguai e das Missões (URI), Erechim, Rio Grande do Sul State, Brazil, in order to identify the species.

\section{Essential Oils (EOs)}

$O$. basilicum and $C$. citratus EOs were extracted by steam distillation in a pilot-scale still made of stainless steel. Initially, about $5 \mathrm{~kg}$ of fresh plant material (aerial parts) were stored in the extraction system. The steam was generated in a boiler and conducted through the plant material to release the aromatic content. After condensation in a refrigerated coil, the aqueous phase was continuously transferred to a settling funnel, where EO was obtained by spontaneous separation of the phases. After two hours of extraction, the crude EO was transferred to a 50 $\mathrm{mL}$ tube containing $0.5 \mathrm{~g}$ of anhydrous $\mathrm{Na}_{2} \mathrm{SO}_{4}$ for the total removal of the water particles. The sample was stirred for 30 seconds and then centrifuged at $2000 \mathrm{~g}$ for 10 minutes at $5^{\circ} \mathrm{C}$. The clear $\mathrm{EO}$ was transferred to an amber glass bottle and stored at $20^{\circ} \mathrm{C}$. The oil sample $(100 \mathrm{mg})$ was dissolved in dichloromethane $(10 \mathrm{~mL})$ and the resulting solution was analyzed by gas chromatography (CG-DIC and CG-EM). The $S$. aromaticum and T. vulgaris EOs were purchased from Ferquima Indústria e Comércio Ltda. (Vargem Grande, Sao Paulo State, Brazil).

\section{Gas chromatography with flame ionization} detection (GC-FID)

The four EOs were analyzed using an Agilent 7820A gas chromatography system (Agilent Technologies, Inc., Shanghai, China) equipped with a split/splitless injector, a flame ionization detector (FID), and an Agilent 7693A autoinjector. The sample solution (1 $\mu \mathrm{L})$ was injected in the split mode at a ratio of $1: 10$. Analyses were performed with an Agilent J\&W HP-5 capillary column $(30 \mathrm{~m} \times 0.25 \mathrm{~mm}$ i.d., 1 ìm film thickness, and stationary phase consisting of $5 \%$ diphenyl/95\% dimethylpolysiloxane). The oven temperature program was as follows: held at $50^{\circ} \mathrm{C}$ for 2 minutes, increased from 50 to $220^{\circ} \mathrm{C}$ at a rate of $2^{\circ} \mathrm{C} / \mathrm{min}$, held at $220^{\circ} \mathrm{C}$ for 3 minutes. Nitrogen was used as carrier gas at a flow rate of $1.2 \mathrm{ml} / \mathrm{min}$. The injector and FID temperatures were fixed $240^{\circ} \mathrm{C}$ and $280^{\circ} \mathrm{C}$, respectively. The flow rates of air, $\mathrm{H} 2$, and $\mathrm{N} 2$ in the FID were 300,30 , and $30 \mathrm{~mL} / \mathrm{min}$, respectively. The OpenLAB CDS software was used for equipment management and data processing. The compositions of the EOs were expressed as a percentage of normalized area. (Babushok et al., 2011; Adams, 2017).

\section{Gas chromatography coupled to mass spectrometry (GC-MS)}

The EOs were analyzed using a Shimadzu GCMSQP2010 gas chromatograph-mass spectrometer (Shimadzu Corporation Technologies, Inc., Tokyo, Japan) equipped with a split/splitless injector. The sample solution $(1 \mu \mathrm{L})$ was injected in the split mode at a ratio of 1:10. Analyses were performed with a Supelco Equity-5 capillary column $(30 \mathrm{~m} \times 0.2 \mathrm{~mm}$ i.d., $0.2 \mu \mathrm{m}$ film thickness, and stationary phase

\section{Boletín Latinoamericano y del Caribe de Plantas Medicinales y Aromáticas / 83}


consisting of $\quad 5 \%$ diphenyl $/ 95 \%$ dimethylpolysiloxane). The oven temperature program was as follows: held at $50^{\circ} \mathrm{C}$ for 2 minutes, increased from 50 to $220^{\circ} \mathrm{C}$ at a rate of $2^{\circ} \mathrm{C} / \mathrm{min}$, and held at $220^{\circ} \mathrm{C}$ for 3 minutes. Helium was used as carrier gas at a flow rate of $1.2 \mathrm{~mL} / \mathrm{min}$ (constant linear velocity of $39.2 \mathrm{~cm} / \mathrm{sec}$ ). The injector temperature was set at $240^{\circ} \mathrm{C}$. The interface and ion source temperatures were fixed at 220 and $200^{\circ} \mathrm{C}$, respectively. Quadrupole mass spectrometer was operated in eléctron impact mode at $70 \mathrm{eV}$, scanning the range $\mathrm{m} / \mathrm{z} 35-350$ in cycles of $0.5 \mathrm{~s}$. The GCMS solution software was used for equipment management and data processing. Compounds were identified by searching the NIST 05 mass spectral library and by comparison of their retention indeces relative to the C7-C30 $n$-alkane series with those values found in literature (Babushok et al., 2011; Adams, 2017; El-Sayed, 2018).

\section{Minimum Inhibitory Concentration Disc-Diffusion test (CMI)}

The detection of the inhibitory effect of the EOs on the tested bacteria was carried out by the agar discdiffusion method based on the document M2-A8 of CLSI (2003a). The EOs were diluted in 100\% PA ethanol (Merck, Germany) in the concentrations: Dilution 1: 50\%; Dilution 2: 25\%; Dilution 3: 12.5\%; Dilution 4: 6.25\%; Dilution 5: 3.12\%; Dilution 6: 1.56\%; Dilution 7: $0.78 \%$ and Dilution 8: 0.39\%. 5 $\mu \mathrm{L}$ of $\mathrm{EO}$ were used for application on filter paper discs (n. 103) measuring $6 \mathrm{~mm}$ in diameter. The negative control was prepared using only the solvent (ethanol). The disks were placed under the plates with Mueller Hinton (MH) culture medium, containing of microorganisms. The plates were incubated at $37^{\circ} \mathrm{C}$ for 24 hours. The MIC was evaluated using a caliper to measure the inhibition halos, when present, considering the diameter of the filter paper disc. The diameter of inhibition zones, including the disc diameter, was measured in millimeters, and inhibition was scored as weak (10$13.9 \mathrm{~mm})$ moderate $(14-18 \mathrm{~mm})$, or strong $(>18 \mathrm{~mm})$, according to Carovic-Stanko et al. (2010). Tests were performed in quadruplicate.

\section{Solution based on EOs}

The solutions based on EOs were obtained according to Millezi et al. (2012), with modifications. PA ethanol (Merck, Germany) was used as diluent. The
EOs were diluted in the concentrations of $0.4 \%$, $0.8 \%$, and $1 \%$ in Triptona Soy Broth - TSB (Oxoid, England) from a $2.5 \%$ EO stock solution (dilution of the EOs in PA ethanol) $2.0 \%$ and $0.85 \%$ saline water).

\section{Biofilm formation}

For the formation of biofilms, the inoculum was standardized at approximately $10^{8} \mathrm{CFU} / \mathrm{mL}$ (through a calibration curve). The bacterium was inoculated into 96-well polypropylene microplates and incubated in an orbital shaker (SOLAB, Brazil) at $37^{\circ} \mathrm{C}$, shaking at $80 \mathrm{rpm}$ for 24 hours, containing treatments with EO-based solutions and a positive control containing only the bacterial suspension in Brain Heart Infusion (BHI) medium (Oxoid, England) at $10^{8} \mathrm{CFU} / \mathrm{mL}$, without oil (Millezi et al., 2012), and the controls containing sterile distilled water to replace the corresponding EO rates of each concentration.

\section{Planktonic cells quantification}

In the quantification of planktonic cells, $100 \mu \mathrm{L}$ of the supernatant from each well was collected, serial dilution and plating were performed on Soy Triptona Agar (TSA) for colony forming units (CFU) counting, using the micro drop technique (Silva et al., 2010). The plates were incubated at $37^{\circ} \mathrm{C}$ (FANEM, São Paulo). After 24 hours, plate counting, values expressed in $\mathrm{CFU} / \mathrm{mL}$ were performed.

\section{Viable cells in biofilm quantification}

For the quantification of viable cells in biofilm, after 24 hours of incubation in an orbital shaker (SOLAB, Brazil), the $200 \mu \mathrm{L}$ aliquots present in each well were discarded, and the microplate was washed twice with sterile distilled water. $200 \mu \mathrm{L}$ of sterile distilled water were placed in each well so that the adhered cells were removed using an ultrasound bath (SANDERS, Brazil), during 5 minutes. A similar procedure of dilution and plating was performed (previously described for the quantification of planktonic cells), however, the values of the plate count were expressed in $\mathrm{CFU} / \mathrm{cm}^{2}$.

\section{Violet crystal biomass quantification}

Biomass biofilms were quantified by adapting the crystal violet $(\mathrm{CV})$ staining method by Stepanovic et al. (2000) and after 24 hours of incubation, the untreated control, containing only culture medium

\section{Boletín Latinoamericano y del Caribe de Plantas Medicinales y Aromáticas / 84}


and the bacterial inoculum, were used to classify the bacteria as biofilm formation capacity. For fixing, it were added $200 \mu \mathrm{L}$ of $99 \%$ methanol (Vaz Pereira, Portugal) to each well containing adhered cells or biofilms treated with EOs, as previously described. After the time of 15 minutes, the methanol was removed and the polystyrene microplates were allowed to dry at room temperature. Then, $200 \mu \mathrm{L}$ of $\mathrm{CV}$ stain $(1 \% \mathrm{v} / \mathrm{v})$ (Merck, Portugal) was added to all wells. After 5 minutes, CV excess was removed and plates were washed in distilled water. Finally, $230 \mu \mathrm{L}$ of acetic acid (33\% v/v) (Pronalab, Portugal) were added to the wells in order to dissolve CV stain, and the absorbance was measured at $630 \mathrm{~nm}$ in spectrophotometer Elisa (Termoplate, Brazil).

\section{Statistical analysis}

The design of the analysis followed in three replications and triplicate. Statistical was performed using Prism version 7.0 (GraphPad Software, Inc., La
Jolla, USA). The assumptions for the parametric test were checked before the analysis. Data was analyzed One-way ANOVA Bonferroni test was performed and $\mathrm{P}<0.05$ was considered significant.

\section{RESULTS}

EOs extraction and chromatographies

Considering the identification of plant specimens, the following denomination was obtained as a result: 1) HPBR 12.086 Ocimum basilicum L. (basil) and 2) HPBR 12.088 Cymbopogon citratus (DC) Stapf (lemongrass). The basil EO presented as main major components the following compounds: linalool $(24.05 \%)$ and 1.8-cineol (13.73\%). For lemongrass, the major compounds were geranial $(40.40 \%)$, neral (29.89\%), and $\beta$-mycrene (17.08\%). Regarding EOs commercial, the main components found were, for thyme: thymol (39.94\%) and p-cymene $(29.92 \%)$; and, for the clove, eugenol predominated with $86.23 \%$; followed by $\beta$-karyophylene with $10.50 \%$.

Table No. 1

Chemical composition (\% in normalized area) and yield of essential oils

\begin{tabular}{lcccccc}
\hline Compound & $\mathbf{R I}^{\mathbf{a}}$ & $\mathbf{R I}^{\mathbf{b}}$ & $\begin{array}{c}\text { Ocimum } \\
\text { basilicum }\end{array}$ & $\begin{array}{c}\text { Cymbopogon } \\
\text { citratus }\end{array}$ & $\begin{array}{c}\text { Thymus } \\
\text { vulgaris }\end{array}$ & $\begin{array}{c}\text { Syzygium } \\
\text { aromaticum }\end{array}$ \\
\hline$\alpha$-Pinene & 932 & 929 & 1,46 & - & - & - \\
Camphene & 946 & 943 & 1,24 & - & - & - \\
Sabineno & 969 & 969 & 1,31 & - & - & - \\
$\beta$-Pinene & 974 & 972 & 2,48 & - & - & - \\
6-Methyl-5-hepten-2-one & 981 & 987 & - & 0,74 & - & - \\
$\beta$-Myrcene & 988 & 990 & 1,69 & 17,08 & 1,54 & - \\
$p$-Cimene & 1020 & 1011 & - & - & 29,92 & - \\
(+)-Silvestrene & 1025 & 1025 & 3,32 & - & 0,86 & - \\
1,8-Cineol & 1026 & 1029 & 13,73 & - & 1,30 & - \\
$(Z$ - $\beta$-Ocimene & 1032 & 1036 & - & 0,41 & - & - \\
$(E)-\beta$-Ocimene & 1044 & 1046 & 0,72 & 0,29 & - & - \\
$\gamma$-Terpinene & 1054 & 1055 & 0,51 & - & 6,81 & - \\
L-Fenchone & 1083 & 1082 & 2,59 & - & - & - \\
Linalool & 1095 & 1101 & 24,05 & 0,80 & 5,82 & - \\
Camphor & 1141 & 1137 & 9,03 & - & 1,41 & - \\
Isoborneol & 1155 & 1146 & - & - & 0,73 & - \\
Borneol & 1165 & 1157 & - & - & 1,33 & - \\
Cis-Verbenol & 1165 & 1164 & - & 1,61 & - & - \\
Terpinen-4-ol & 1174 & 1174 & 0,40 & - & 1,03 & - \\
4,5 -Epoxy-carene & - & 1182 & - & 2,18 & - & - \\
$\alpha$-Terpineol & 1186 & 1188 & 1,31 & - & - & - \\
Neral & 1235 & 1242 & - & 29,89 & - & - \\
& & & & & -
\end{tabular}

Boletín Latinoamericano y del Caribe de Plantas Medicinales y Aromáticas / 85 


\begin{tabular}{|c|c|c|c|c|c|c|}
\hline Geraniol & 1249 & 1257 & - & 3,11 & - & - \\
\hline Geranial & 1264 & 1273 & - & 40,40 & - & - \\
\hline 2-Undecanone & 1293 & 1294 & - & 0,26 & - & - \\
\hline Thymol & 1289 & 1295 & - & - & 39,94 & - \\
\hline Carvacrol & 1298 & 1302 & - & - & 6,38 & - \\
\hline Eugenol & 1356 & 1355 & 6,46 & - & - & 86,23 \\
\hline Geranyl acetate & 1379 & 1385 & - & 0,39 & - & - \\
\hline$\beta$-Elemene & 1389 & 1383 & 3,37 & - & - & - \\
\hline$\beta$-Caryophyllene & 1417 & 1412 & 4,02 & - & 1,37 & 10,50 \\
\hline (E)- $\alpha$-Bergamoteno & 1432 & 1427 & 2,38 & - & - & - \\
\hline$\alpha$-Caryophyllene & 1444 & 1441 & 1,06 & - & - & 2,37 \\
\hline Germacrene D & 1480 & 1469 & 8,14 & - & - & - \\
\hline Germacrene A & 1484 & 1486 & 0,92 & - & - & - \\
\hline 2-Tridecanone & 1495 & 1495 & - & 0,19 & - & - \\
\hline$\alpha$-Muurolene & 1500 & 1502 & 1,78 & - & - & - \\
\hline Cubenol & 1637 & 1614 & 0,57 & - & - & - \\
\hline Cadinol & 1640 & 1629 & 3,48 & - & - & - \\
\hline \multirow{2}{*}{\multicolumn{3}{|c|}{$\begin{array}{l}\text { Total identified }(\%) \\
\text { Essential oil yield } \quad(\% \\
\mathrm{m} / \mathrm{m} \text { as dry basis })\end{array}$}} & 96,03 & 97,35 & \multirow{2}{*}{$\begin{array}{c}93,44 \\
*\end{array}$} & \multirow{2}{*}{$\begin{array}{c}99,10 \\
*\end{array}$} \\
\hline & & & 0,40 & 0,63 & & \\
\hline
\end{tabular}

The results of the Disc-Diffusion test demonstrated the formation inhibition halos. EO $T$. vulgaris presented strong inhibitory action against $E$. coli, S. aromaticum showed moderate inhibition, and C. citratus weak, according to Carovic-Stanko et al. (2010). Ocimum basilicum EO showed MIC at $12.5 \%$ concentration, however, the halos were smaller than 9 $\mathrm{mm}, E$ coli was considered resistant to this oil in this test (Figure No. 1). The lowest MIC was T. vulgaris oil, being $3.125 \%$, for $C$. citratus and $S$. aromaticum oils the MIC was $6.125 \%$.

\section{Biofilm formation}

EOs showed significant activity against viable planktonic cells (Figure No. 2), there was bacterial growth only in the $1.0 \%$ concentration, when $T$. vulgaris EO was used, however, this growth was less than the control without treatment $(p<0,05)$.

The results of treatments using solutions with EOs on viable cells in biofilms differ from those reported for planktonic cells. In none of the concentrations $O$. basilicum EO (Figure No. 3b), there was a significant microbial reduction $(p>0.05)$.
The T. vulgaris EO (Figure No. 3a) effective only at concentrations of $0.4 \%$ and $0.8 \%$, with reductions being respectively 3.4 and $3.1 \log$ cycles. For the $S$. aromaticum EO (Figure No. 3d), there was a reduction in all concentrations, and in $0.4 \%$ there was a decrease of $1.43 \mathrm{log}$ cycles, for the $0.8 \%$ concentration the reduction was of $3.1 \mathrm{log}$ cycles and in $1 \%$ the reduction was $3.2 \operatorname{logs}$ cycles. Cymbopogon citratus EO was significantly efficient in two concentrations studied in this work $(p>0.05)$, there was a reduction of $2.3 \log$ cycles in the concentration of $0.8 \%$, already in $1.0 \%$ of EO, no bacterial growth was observed, therefore, there is a $100 \%$ reduction in viable cells in the biofilm.

Figure No. 4 shows the results of the effects of EOs on E. coli biomass. In the treatment with EO of T. vulgaris (Figure No. 3a), the concentrations $0.4 \%$ and $0.8 \%$ showed a significant reduction $(p<$ $0.05)$, being $59 \%$ and $53 \%$, respectively. The percentage biomass reduction with $O$. basilicum EO treatment for the $0.4 \%, 0.8 \%$ and $1.0 \%$ concentrations was $53 \%, 59 \%$ and $49 \%$, respectively $(p<0.05)$ (3b). There was significant biomass 
reduction in three concentrations of $C$. citratus EO, with $57 \%$ in the lowest concentration $(0.4 \%), 42 \%$ reduction in the intermediate concentration $(0.8 \%)$ and in $1.0 \%$ EO there was a $37 \%$ decrease of biomass. The reduction with the treatment using the
EO of $S$. aromaticum (3d), as well as in the EO of $T$. vulgaris, demonstrated significant biomass reduction in concentrations of $0.4 \%$ (44\% reduction) and $0.8 \%$ (46\% reduction).

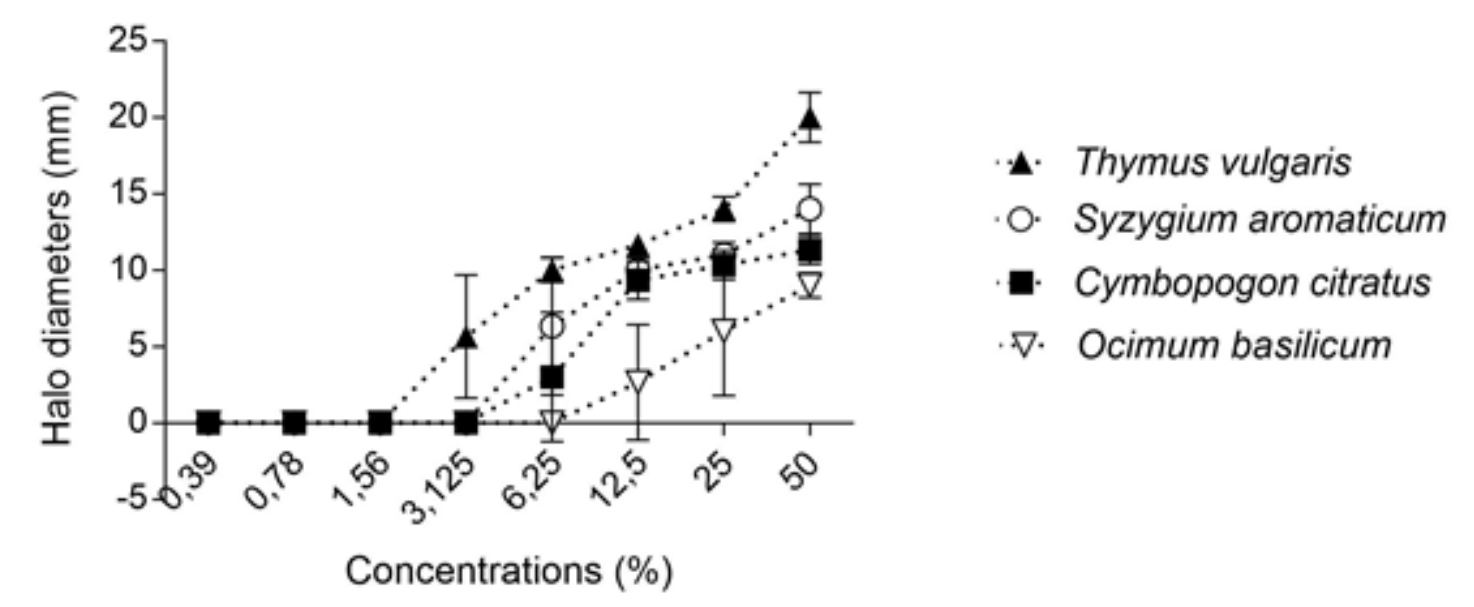

Figure No. 1

Inhibition zones by different concentrations of EOs on Escherichia coli
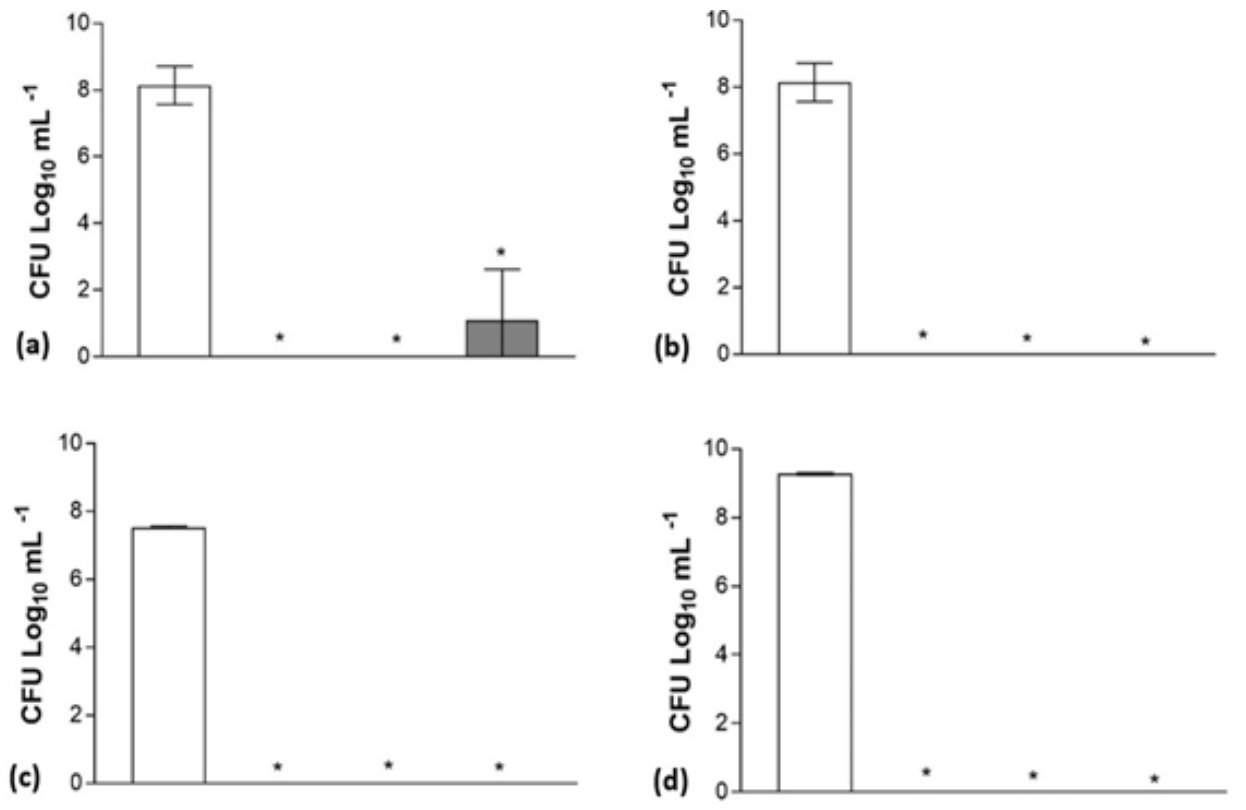

Control 0\%

$0.4 \%$

$0.8 \%$

$1.0 \%$

Figure No. 2

Action of essential oils on viable $E$. coli plactonic cells. (a) T. vulgaris (b) O. basilicum; (c) C. citratus; (c) $S$. aromaticum. The values refer to the average of three repetitions and the bars indicate the standard deviation. $* p<0.05$ according to ANOVA

Boletín Latinoamericano y del Caribe de Plantas Medicinales y Aromáticas / 87 

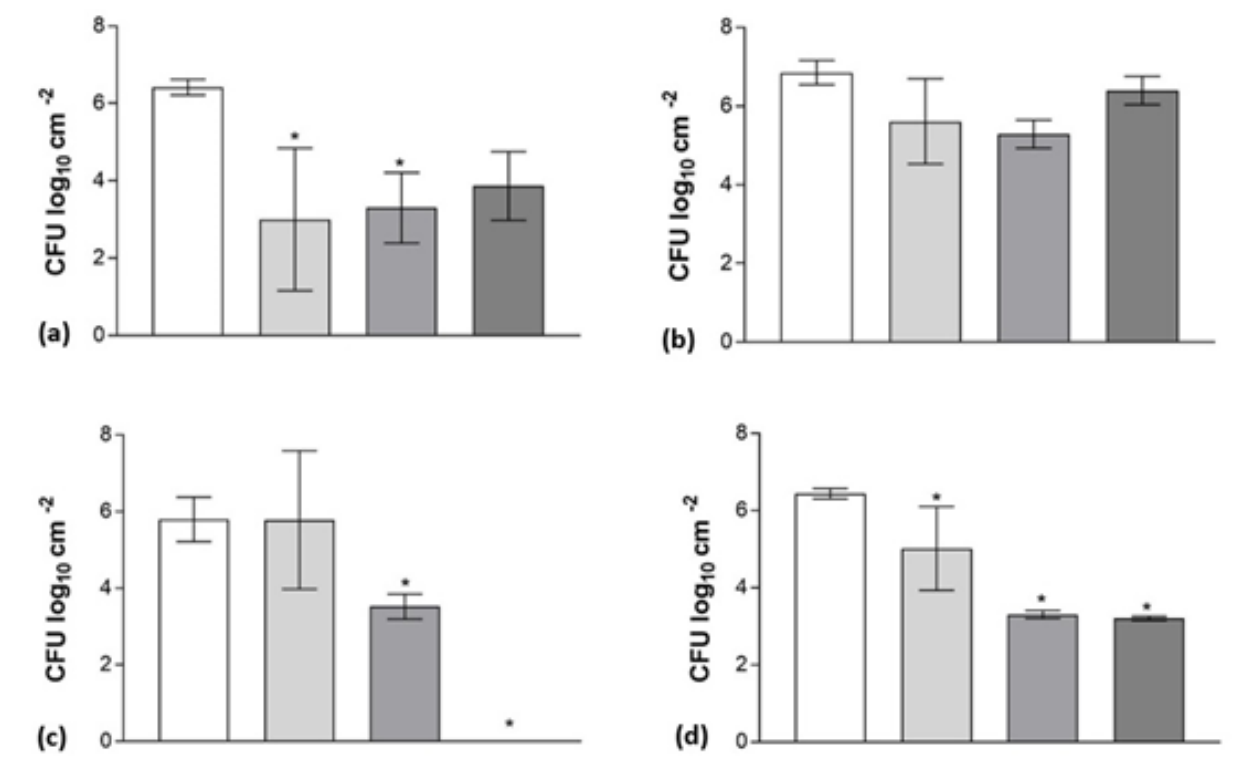

Control $0 \% \square 0.4 \%$

$0.8 \% \square 1.0 \%$

Figure No. 3

Action of essential oils on viable cells in $E$. coli biofilms. (a) T. vulgaris (b) O. basilicum; (c) C. citratus; (c) $S$. aromaticum. The values refer to the average of three repetitions and the bars indicate the standard deviation. * $p<0.05$ according to ANOVA

\section{DISCUSSION}

In some studies, the activity of Eos is reported. As they are a complex mixture of substances, they are described as antimicrobial (Nikolic et al., 2014; Millezi et al., 2016; Dalla Costa et al., 2019; Camargo et al., 2020). In another conception, some studies emphasize that some isolated components are responsible for this activity (Chubukov et al., 2015; Lopez-Romero et al., 2015, Shi et al, 2016). Among these perspectives, it should be considered that EOs have their variable constitution, according to abiotic factors, such as temperature, seasonality, soil type (availability of micro and macronutrients), light intensity and even atmospheric pollution (GobboNetto \& Lopes, 2007), as well as the synergism between the different constituents, so that this mixture between majority and minority compounds is what can be effective against microorganisms (Oliveira et al., 2012).

In the composition $O$. basilicum EO, 24 components were identified, with a total identification of $96.03 \%$. Among these compounds, the following stand out: 1,8-cineole (13.73\%); camphor $(9.03 \%)$, and linalool $(24.05 \%)$. However, according to Silva et al. (2017) the compounds linalool, 1-8 cineol, and geraniol were found in greater quantity, being $95 \%$ of the EO content. In the studies by Valeriano et al. (2012), the EO of O. basilicum had $59.19 \%$ linalool in the constitution, $13.74 \%$ of 1.8 cineole. Both studies highlighted linalool as possibly responsible for the O. basilicum bacterial activity.

For the EO $S$. aromaticum results, Nascimento et al. (2016) reported as major components eugenol (80.67\%) and eugenol acetate, with (11.92\%). A similar result was reported by Budri et al. (2015), eugenol represented 90.2\%, followed by eugenol acetate with $6.5 \%$. In the present study, eugenol was predominant with $86.23 \%$; followed by the compound b-Karyophylene with $10.50 \%$, thus representing $96.73 \%$ of the total compounds.

The $C$. citratus EO presented as major compounds geranial (40.40\%), neral (29.89\%), and $\beta$-Myrcene (17.08\%). According to several other reports found in the literature, these compounds are generally found as major constituents EO C. citratus (Oliveira et al., 2010; Millezi et al., 2013; Oliveira et al., 2012).

Boletín Latinoamericano y del Caribe de Plantas Medicinales y Aromáticas / 88 

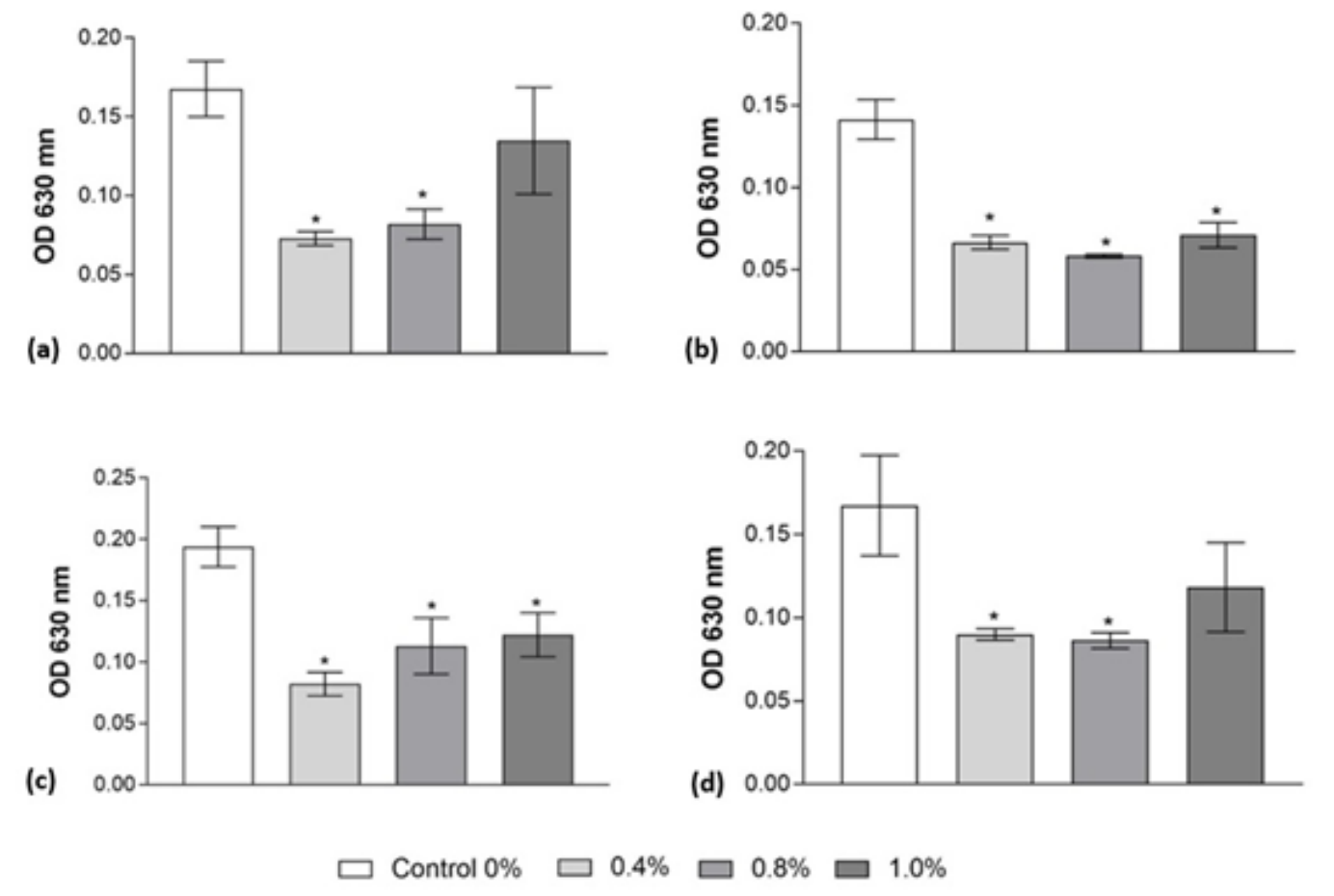

Figure No. 4

Action of essential oils on biomass E. coli. (a) T. vulgaris (b) O. basilicum; (c) C. citratus; (c) S. aromaticum. The values refer to the average of three repetitions and the bars indicate the standard deviation. $* p<0.05$ according to ANOVA

In the antibacterial activity of EOs, the analysis of the determination of Minimum Inhibitory Concentration (CMI), can be controversial, since there are several different methodologies for this approach. Although used in several studies (CarovicStanko et al., 2010; Alexopoulos et al., 2011; Millezi et al., 2013; Stanojevic et al., 2017), analyzes using the Disc-Diffusion methodology, for example, can present variations, depending on the adaptations used, since the recommendation of this methodology is for antibiotics and the EOs have different and peculiar chemical characteristics. In this work, we used this methodology, however, we found that in the analysis of CFU counting, there was a divergence of the results found for the $C$. citratus $\mathrm{EO}$, proving the need to use complementary and more reliable analyzes than just the CMI measurement techniques.

The EOs used in this research demonstrated a significant effect against $E$. coli in a planktonic state, there was a reduction of cells in all treatments; however, it was found that there was a potential for biotransfer of planktonic bacteria to the surface, since the presence of sessile cells was confirmed, presenting greater resistance. Szczepanski and Lipski (2014) and Millezi et al. (2016) described in their researches greater resistance of cells in biofilm, when compared with planktonic cells, treated with EOs. The great problem of the formation of biofilms on surfaces is confirmed, and the difficulty in completely eradicating these communities.

The use of EOs against bacteria is justified due to its cytotoxic activity (Bakkali et al., 2008). This effect is dependent not only on the chemical composition but also on the state of the division of the pathogenic organism (Bakkali et al., 2008). Also, because they are lipophilic compounds, these constituents act through the cell wall and membrane, causing their permeabilization; as a consequence, the

Boletín Latinoamericano y del Caribe de Plantas Medicinales y Aromáticas / 89 
leakage of cellular materials, such as ATP and nucleic acids, is observed; inducing coagulation of the cytoplasm; and damaging lipids and proteins, leading to cell destruction (Bakkali et al., 2008; Raut \& Karuppayil, 2014).

According to the parameters proposed by Stepanovic et al. (2000) for the formation of biofilm, the bacteria demonstrated to be moderately biofilmforming, confirming the ability of this strain to adhere to animal tissues, causing infection. Biofilms proliferate in environments, releasing planktonic cells that colonize other surfaces, in the case of E. coli, diseases occur in swine that negatively affect the development of animals and the respective zootechnical indexes. Once the bacteria has spread in the environment where the animals are handled, infection is facilitated. Bacteria isolated from different niches typically exhibit different abilities to adhere to the substrate and form biofilms. Such distinct abilities depend not only on the characteristics of the surface and the environment around the microorganism (nutrients, ionic strength, $\mathrm{pH}$, and temperature) but also on its phenotype and genotype. The infected animal excretes the bacteria in feces, contaminating the environment, so if the site is not effectively sanitized and disinfected, animal reinfection cycles occur (Dias et al., 2018).

The results of this study showed a promising antibiofilm action, by the EOs of $S$. aromaticum, $T$. vulgaris, and C. citratus. The reduction of $100 \%$ of the cells in biofilm in the concentration of $1 \%$ of the oil of $C$. citratus, confirms that there was total eradication of the microorganism, and the reduction in biomass of the biofilm corroborated with the reduction of viable cells, this result is very important. In contrast, no concentration $O$. basilicum EO was effective in reducing viable cells. In higher concentrations of EOs of $T$. vulgaris and $S$. aromaticum at $1 \%(p>0.05)$ it was found that the effectiveness was lower in reducing biomass. These results indicate that high concentrations do not necessarily determine adequate antimicrobial action, since the sites of action of antibacterial substances may already be occupied with these molecules, making it unnecessary to use higher concentrations. This fact corroborates the question proposed by Ohno et al. (2003), that the development of microbial resistance to EOs is more difficult. Another factor, in this context, is the issue of the differentiated constitution of EOs, the synergism between the various chemical substances that compose them.

\section{CONCLUSION}

Innovative sanitizing solutions can be developed with the use of EOs. The oils evaluated in this research showed the ability to reduce planktonic cells, although biofilms have shown greater resistance. $S$. aromaticum demonstrated efficiency by reducing CFU of planktonic cells and biofilm, as well as the $E$ coli biomass, also demonstrating that lower concentrations may be more effective. Studies testing the activity of these EOs against other bacteria can be challenging and efficient in new perspectives. We highlight the ability of $C$. citratus EO, demonstrated in the in vitro tests of this study, to fully inhibit the growth of the E. coli proves its bactericidal efficacy. Other tests can be carried out to investigate the recovery capacity of planktonic and sessile cells, in addition to in vivo studies to combat the formation of biofilms as a prevention of diseases caused by $E$. coli in swine.

\section{REFERÊNCIAS}

Adams RP. 2017. Identication of essential oil components by gas chromatographic/mass spectrometry. Allured Publishing, Carol Stream, Illinois, USA.

Alexopoulos A, Kimbaris AC, Plessas S, Mantzourani I, Theodoridou I, Stavropoulou E, Polissiou MG, Bezirtzoglou E. 2011. Antibacterial activities of essential oils from eight Greek aromatic plants against clinical isolates of Staphylococcus aureus. Anaerobe 17: 399 - 402.

https://doi.org/10.1016/j.anaerobe.2011.03.024

Bakkali F, Averbeck S, Averbeck D, Idaomar M. 2008. Biological effects of essential oils - A review. Food Chem Toxicol 46: 446 - 475. https://doi.org/10.1016/j.fet.2007.09.106

Babushok VI, Linstrom PJ, Zenkevich IG. 2011. Retention indices for frequently reported compounds of plant essential oils. J Phys Chem Ref Data 40: 1 - 47. https://doi.org/10.1063/1.3653552

Barcellos D, Oliveira S.J. 2012. Doenças relacionadas ao efeito do gene de estresse suínos (RyR1). In: 
Sobestiansky J \& Barcellos D. (Eds), Doenças dos Suínos. Cânone Editorial, Goiânia, Brasil.

Budri PE, Silva NCC, Bonsaglia ECR, Fernandes Júnior A, Araújo Júnior_JP, Doyama JT, Gonçalves JL, Santos MV, Fitzgerald-Hughes D, Rall VLM. 2015. Effect of essential oils of Syzygium aromaticum and Cinnamomum zeylanicum and their major components on biofilm production in Staphylococcus aureus strains isolated from milk of cows with mastitis. J Dairy Sci 98: 5899 - 5904.

https://doi.org/10.3168/jds.2015-9442

Caramori Júnior JG, Araújo GM, Vieites FM, Abreu JG, Cochove VC, Silva GS. 2010. Causas de mortalidade em leitões em granja comercial do médio-norte de mato grosso. Rev Bras Cienc Vet 17: 12 - 15. https://doi.org/10.4322/rbcv.2014.136

Camargo KC, Batista, LR, Alves E, |Rezende DACS, Teixeira ML, Brandão, RM, Ferreira VRF, Nelson DL, Cardoso MG. 2020. Antibacterial action of the essential oil from Cantinoa carpinifolia benth. Against Escherichia coli and Staphylococcus aureus strains. Flav Fragr J 35: 99 - 106. https://doi.org/10.1002/ffj.3541

Cardoso MG, Gavilanes ML, Marques MC, Shan AYKV, Santos BR, Oliveira ACB, Bertolucci SKV, Pinto APS. 2000. Óleos essenciais. Boletim Técnico - Série Extensão 8: 1 - 42.

Carovic-Sanko K, Orlić S,Politeo O, Strikić F, Kolak I, Milos M, Satovic Z. 2010. Composition and antibacterial activities of essential oils of seven Ocimum taxa. Food Chem 119: 196 - 201. https://doi.org/10.1016/j.foodchem.2009.06.010

Chubukov V, Mingardon F, Schackwitz W, Baidoo EEK, Alonso-Gutierrez J, Hu Q, Lee TS, Keasling JD, Mukhopadhyay A. 2015. Acute limonene toxicity in Escherichia coli is caused by limonene hydroperoxide and alleviated by a point mutation in alkyl hydroperoxidase AhpC. Appl Environ Microbiol 81: 4690 4696. https://doi.org/10.1128/aem.01102-15

CLSI. 2003. [Clinical and Laboratory Standards Institute]. Performance standards for antimicrobial disk susceptibility tests: approved standard. Pennsylvania, USA.

Dalla Costa KA, Moura R, Millezi AF. 2019. Antimicrobial and antibiofilm activity of Cymbopogon flexuosus essential oil microemulsions. Rev Ceres 66: 372 - 379. https://doi.org/10.1590/0034-737x201966050006

Dias NDS, Melo D, Araújo JDL, Maciel GDS, Gomes Filho AAH, Dos Santos ES, Braga C. 2018. Respostas preliminares de progênies de cajueiro-anão à infestação da broca-das-pontas e da traça-da-castanha. Embrapa Agroindústria Tropical, Bol Pesquisa Desenvolvimento 156. www.infoteca.cnptia.embrapa.br

Donlan, RM. 2002. Biofilms: Microbial life on Surfaces. Emerg Infec Dis 8: 881 - 890. https://doi.org/10.3201/eid0809.020063

El-Sayed AM. 2018. The Pherobase: Database of pheromones and semiochemicals. http://www.pherobase.com

Essawi T, Srour M. 2000. Screening of some Palestinian medicinal plants for antibacterial activity. J Ethnopharmacol 70: 343 - 349. https://doi.org/10.1016/s0378-8741(99)00187-7

Gobbo-Neto L, Lopes NP. 2007. Plantas medicinais: fatores de influência no conteúdo de metabólitos secundários. Quím Nova 30: 374 - 381. https://doi.org/10.1590/s0100-40422007000200026

Gomes PRB, Silva ALS, Pinheiro HA, Carvalho LL, Lima HS, Silva EF, Silva RP, Louzeiro CH, Oliveira MB, Filho VEM. 2016. Avaliação da atividade larvicida do óleo essencial do Zingiber officinale Roscoe (gengibre) frente ao mosquito Aedes aegypti. Rev Bras Plant Med 18: 597 - 604.

https://doi.org/10.1590/1983-084x/15_214

Gajendiran A, Thangaraman V, Thangamani S, Ravi D, Abraham, J. 2016. Antimicrobial, antioxidant and anticancer screening of Ocimum basilicum seeds. Bull Pharm Res 6: 114 - 119.

Guimarães LGL, Cardoso MG, Sousa PE, Andrade J, Vieira SS. 2011. Atividades antioxidante e fungitóxica do óleo essencial de capim-limão e do citral. Rev Ciênc Agron 42: 464 - 472.

https://doi.org/10.1590/s1806-66902011000200028

Gupta, SK, Prakash J. and Srivastava, S. 2002. Validation of traditional claim of Tulsi Ocimum sanctum Linn. as a a medicinal plant. Ind J Exp Biol 40: 765 - 773.

Isman MB. 2000. Plant essential oils for pest and disease management. Crop Prot 19: 603 - 608.

https://doi.org/10.1016/s0261-2194(00)00079-x

Lopez-Romero JC, González-Ríos H, Borges A, Simões M. 2015. Antibacterial effects and mode of action of selected essential oils components against Escherichia coli and Staphylococcus aureus. Evid-Based Complement Alt Med 1-9. https://doi.org/10.1155/2015/795435

Boletín Latinoamericano y del Caribe de Plantas Medicinales y Aromáticas / 91 
Machado SR, Barbosa SB. 2010. Regulamento. Herbário Irina Delanova de Gemtchujnicov, Departamento de Botânica - Campus de Botucatu, Instituto de Biociências, Universidade Estadual Paulista, Sao Paulo, Brasil.

Millezi AF, Caixeta DS, Rossoni DF, Cardoso MG, Piccoli RH. 2012. In vitro antimicrobial properties of plant essential oils Thymus vulgaris, Cymbopogon citratus and Laurus nobilis against five important foodborne pathogens. Ciênc Tecnol Aliment 32: 167 - 172. https://doi.org/10.1590/s0101-20612012005000021

Millezi AF, Cardoso MG, Alves E, Piccoli RH. 2013. Reduction of Aeromonas hidrophyla biofilm on stainless stell surface by essential oils. Braz J Microb 44: 73 - 80. https://doi.org/10.1590/s1517-83822013005000015

Millezi AF, Piccoli RH, Oliveira JM, Pereira MO. 2016. Anti-biofim and antibacterial effect of essential oils and their major compounds. J Essent Oil Bear Plants 19: 624 - 631.

https://doi.org/10.1080/0972060x.2014.960262

Nascimento AA, Reis JB, Filho VEM. 2016. Atividade larvicida do óleo essencial de cravo-da-índia: Extração, caracterização e atividade larvicida frente ao mosquito Aedes aegypti. Editora Novas Edições Acadêmicas, International Book Market Service, Riga, Letônia.

Nikolic M, Glamoclija J, Ferreira ICFR, Calhelha RC, Fernandes A, Markovic T, Markovic D, Giweli A, Sokovic M. 2014. Chemical composition, antimicrobial, antioxidant and antitumor activity of Thymus serpyllum L., Thymus algeriensis Boiss. and Reut and Thymus vulgaris L. essential oils. Ind Crops Prod 52: 183 - 190. https://doi.org/10.1016/j.indcrop.2013.10.006

Ohno T, Kita M, Yamaoka Y, Imamura S, Yamamoto T, Mitsufuji S, Kodama T, Kashima K, Imanishi J. 2003. Antimicrobial activity of essential oils against Helicobacter pylori. Helicobacter 8: 207 - 215. https://doi.org/10.1046/j.1523-5378.2003.00146.x

Oliveira MMO, Brugnera DF, Cardoso MG, Alves E, Piccoli RH. 2010. Disinfectant action of Cymbopogon sp. essential oils in different phases of biofilm formation by Listeria monocytogenes on stainless steel surface. Food Control 21: 549 - 553. https://doi.org/10.1016/j.foodcont.2009.08.003

Oliveira MMO, Brugnera DF, Nascimento JA, Piccoli RH. 2012. Control of planktonic and sessile bacterial cells by essential oils. Food Biop Proc 90: 809 - 818. https://doi.org/10.1016/j.fbp.2012.03.002

Pauliquevis CF, Favero S. 2015. Atividade insetistática de óleo essencial de Pothomorphe umbellata sobre Sitophilus zeamais. Rev Bras Eng Agric Amb 19: 1192 -1196.

https://doi.org/10.1590/1807-1929/agriambi.v19n12p1192-1196

Raut JS, Karuppayil SM. 2014. A status review on the medicinal properties of essential oils. Ind Crops Prod 62: 250 - 264. https://doi.org/10.1016/j.indcrop.2014.05.055

Saeed M, Nadeem M, Khan MR, Shabbir, MA, Shehzad A, Amir RM. 2013. Antimicrobial activity of Syzygium aromaticum extracts against food spoilage bactéria. Afric Microb Res 7: 4848 - 4856.

Shi C, Song K, Zhang X, Sun Y, Sui Y, Chen Y, Jia Z, Sun H., Sun Z. Xia X. 2016. Antimicrobial activity and possible mechanism of action of Citral against Cronobacter sakazakii. Plos One 11: e0159006. https://doi.org/10.1371/journal.pone.0159006

Silva N, Junqueira VCA, Silveira NFA, Taniwaki MH, Santos RFS, Gomes RAR. 2010. Manual de métodos de análise microbiológica de alimentos e água. Varela, São Paulo, Brasil.

Silva CVO, Oliveira AMA de, Bezerra PPN, Evangelista JN. 2015. Escherichia coli na suinocultura. Aspectos clínicos. Uma revisão. Rev Bras Hig San Anim 9: 288 - 293.

https://doi.org/10.5935/1981-2965.20150028

Silva LL, Balconi LS, Gressler LT, Garlet QI, Sutili FJ, Vargas AC. 2017. S-(+)- and R-(-)-linalool: a comparison of the in vitro anti-Aeromonas hydrophila activity and anesthetic properties in fish. An Acad Bras Cienc 89: 203 - 212. https://doi.org/10.1590/0001-3765201720150643

Simões CMO, Spitzer V. 2004. Óleos voláteis. In: Simões CMO, Schenkel EP, Gosmann G, Mello JCP, Mentz LA, Petrovick PR: Farmacognosia, da planta ao medicamento. Universidade Federal do Rio Grande do Sul, Porto Alegre, Brasil.

Stanojevic PL, Marjanovic-Balaban, Z.R, Kalaba VD, Stanojevic JS, Cvetkovic DJ, Cakic MD. 2017. Chemical composition, antioxidant and antimicrobial activity of Basil (Ocimum basilicum L.) essential oil. J Essent Oil Bear Plants 20: 1557 - 1569. https://doi.org/10.1080/0972060x.2017.1401963

Stepanovic S, Vukovic D, Dakic I, Savic B, Svabic-Vlahovic M. 2000. A modified microtiter-plate test for quantification of staphylococcal biofilm formation. J Microb Met 40: 175 - 179.

Boletín Latinoamericano y del Caribe de Plantas Medicinales y Aromáticas / 92 
https://doi.org/10.1016/s0167-7012(00)00122-6

Stewart PS, Costerton JW. 2005. Antibiotic resistance of bacteria in biofilms. Lancet 358: 135 - 138. https://doi.org/10.1016/s0140-6736(01)05321-1

Szczepanski S, Lipski A. 2014. Essential oils show specific inhibiting effects on bacterial biofilm formation. Food Cont 36: 224 - 229. https://doi.org/10.1016/j.foodcont.2013.08.023

Valeriano C, De Oliveira TLC, De Carvalho SM, das Graças Cardoso M, Alves E, Piccoli RH. 2012. The sanitizing action of essential oil-based solutions against Salmonella enterica serotype Enteritidis S64 biofilm formation on AISI 304 stainless steel. Food Cont 25: 673 - 677. https://doi.org/10.1016/j.foodcont.2011.12.015

Velluti A, Sanchis V, Ramos AJ, Marin S. 2003. Inhibitory effect of cinnamon, clove, lemongrass, oregano and palmarose essential oils on growth and fumonisin B1 production by Fusarium proliferatum in maize grain. Int J Food Microbiol 89: 145 - 154. https://doi.org/10.1016/s0168-1605(03)00116-8 